\title{
Clinico-pathological profiles of sub-fertility in Zebu Cows
}

\author{
K. F. Pariza*, A. S. M. Bari, F. Y. Bari ${ }^{1}$, M. G. S. Alam² and M. Noor \\ Department of Pathology, Faculty of Veterinary Science, Bangladesh Agricultural \\ University, Mymensingh-2202, Bangladesh
}

\begin{abstract}
Blood samples from cows with reproductive problems (anoestrus, repeat breeder, uterine infection) were collected for haematological, biochemical and humoral immune response analyses. The erythrocyte sedimentation rate (ESR) was higher and haemoglobin $(\mathrm{Hb})$ lowers in subfertile cows than innormal cycling cows. The packed cell volume (PCV) was lower in anoestrus and repeat breeding cows than in control. Total erythrocyte count (TEC) was not significantly different, whereas total leukocyte count (TLC) significantly higher $(p<0.01)$ in anoestrus and repeat breeder cows. The bilirubin concentration was significantly higher $(\mathrm{p}<0.005)$ in anoestrus and uterine infected cows compared with control. The mean serum IgG was lower in all subfertile cows than control. It is suggested that there is no specific clinico-pathological marker for reproductive disorders in cows. (Bangl. vet. 2009. Vol. 26, No. 1, 1-7)
\end{abstract}

\section{Introduction}

Sub-fertility in cows is an important hindrance to dairy farmers (Serur et al., 1982; Albin et al., 1989; Jainuddin and Hafez, 1993). The causes are many, including management, type of service, uterine infection, oestrus detection, nutrition, and immune status. Defective management can increase sub-fertility (Shamsuddin et al., 1988). Important reproductive disorders encountered in Bangladesh are anoestrus, repeat breeder, endometritis, and repeated conception failure (Samad et al., 1978, Vale, 1997) causing considerable economic loss (Jainuddin and Hafez, 1993). Several reports have implicated various blood chemical constituents in sub-fertile cows (Serur et al., 1982; Albin et al., 1989; Dhaliwal et al., 1996; Hoeben et al., 2000), but no such reports are available in Bangladesh.

The present investigation was undertaken to evaluate the haematological and biochemical profiles of cows with reproductive problems in Bangladesh.

\section{Materials and Methods}

Animals selected

A total of 30 lactating multiparous mixed breed cows weighing 220 - $355 \mathrm{~kg}$ were divided into three groups, Group A $(n=7)$ : were suffering from postpartum anoestrus of more than 90 days (Chowdhury et al., 1998); Group B ( $=10)$ : were

${ }_{1 \& 2}$ Department of Surgery \& Obstetrics, Faculty of Veterinary Science, Bangladesh Agricultural University, Mymensingh, Bangladesh

*Correspondence: E-mail:- bari.bau.bd@gmail.com 
repeat breeders (Zemjanis, 1980) and Group C $(n=13)$ : had suspected uterine infection (Sheldon et al., 2003). All were outpatients at the Veterinary Clinic. For control (Group D), cycling lactating multiparous cows $(n=30)$ of mixed breeds were selected from the university dairy farm. Cows belonged to small-holders where only one to 15 cows were kept. They normally maintained their animals on rice straw cutand-carry grass and limited grazing on roadside and community land as forage; and milling by-product as concentrate (rice polish, wheat bran, mustard and til oil cakes fed at 1-2 kg per 1.5 - 2.0 litres of milk). There was no system for oestrus detection, but farmers relied on visible signs of oestrus.

Blood sampling: Five-ml blood was collected from each cow by jugular vein puncture using $10 \mathrm{ml}$ plastic syringe on the first day after examination and every week for three weeks. Half the blood sample was kept with heparinized saline for routine haematological examination; rest of the sample was taken in vials for collection of serum. Serum samples were kept at $-20^{\circ} \mathrm{C}$ until analyzed.

Haematological studies: Erythrocyte sedimentation rate (ESR), Packed cell volume $(\mathrm{PCV})$, Haemoglobin percentage $(\mathrm{Hb} \%)$, Total erythrocyte count (TEC), Total leukocyte count (TLC) and Differential leukocyte count (DLC) were carried out as described by Coffin (1953).

Total serum protein assay: Total blood protein was measured using Folin-phenol method (Lowry et al., 1951). Briefly, a standard curve was made with equilibrated (200 $\mu$ distilled water) bovine serum albumin solution $(1 \mathrm{mg} / \mathrm{ml})$ ranging from 0 to $60 \mu$. Unknown serum samples $(10 \mu \mathrm{l})$ were taken in separate tubes after similar equilibration. After addition of prepared solution (one $\mathrm{ml}$ ), each tube was incubated in a dark place for 30 minutes at room temperature. The absorbance of standard proteins at $660 \mathrm{nmol}$ using spectrophotometer was plotted against concentration of BSA and the concentrations of proteins were extrapolated by putting the value of optical density (OD) in the standard curve.

Serum bilirubin was measured using the standard technique of Harrison and Barlow (1989). Briefly, five-ml methanol, one-ml diazo reagent and four-ml diazo blank were taken as blank sample. For unknown serum sample, five-ml methanol, one-ml diazo reagent and four-ml 1: 10 diluted serum were mixed thoroughly and incubated for 30 minutes at room temperature. The blank was set at $100 \%$ at $540 \mathrm{~nm}$ and the $\%$ of transmission ( $\mathrm{T}$ ) was read in the unknown sample. The result of $\% \mathrm{~T}$ was then converted to $\mathrm{mg} / \mathrm{dl}$.

Serum immunoglobulin-G (IgG): IgG was estimated by the single radial immunediffusion technique (Mancini et al., 1965). The polyclonal antibody IgG was raised by immunizing New Zealand White Rabbit with purified $0.5 \mathrm{mg} / \mathrm{ml}$ Bovine IgG (Sigma, USA). Blood (Serum) was collected from ear vein every week after the first booster 
dose. Sera were used to check the antibody response and quantify the antigen by double immuno-diffusion test and single radial immuno-diffusion technique, respectively, following the procedures described by Bari (1989). The antibovine IgG was titrated using ELISA technique (Bari 1989) in 5 fold dilutions starting from 1 in 50. All the data were analyzed by comparison between groups using students " $t$ " test (Bailey, 1981).

\section{Results and Discussion}

Haematological examination: The results are shown in Table 1. The mean values of ESR in $\mathrm{mm} / 24$ hour were $9.3 \pm 2.6 ; 11.1 \pm 5.6 ; 15.5 \pm 7.3$ and $7.5 \pm 1.2$ in anoestrus (Group A), repeat breeder (Group B), uterine infection (group C) and control (Group D), respectively. The mean values of ESR were significantly higher in problem groups than in control group (A: $\mathrm{p}<0.05 ; \mathrm{B}: \mathrm{p}<0.001$ and $\mathrm{C}: \mathrm{p}<0.001$ ). The mean $\mathrm{Hb} \%$ in Groups A, B, C and D were 10.2 $\pm 1.5,9.6 \pm 1.1,9.7 \pm 7.3$ and 13.1 \pm 2.6 , respectively. $\mathrm{The} \mathrm{Hb}$ concentration was significantly lower in problem groups than in control: (A: $\mathrm{p}<0.05 ; \mathrm{B}: \mathrm{p}<0.01$ and $\mathrm{C}: \mathrm{p}<0.01)$. The mean PCV\% in groups $\mathrm{A}, \mathrm{B}, \mathrm{C}$ and $\mathrm{D}$ were 31.3 $\pm 5.2,28.7 \pm 7.0,38.1 \pm 12.8$ and $43.2 \pm 7.9$, respectively. PCV in Groups A and B were significantly lower than Group D, The TEC of Groups A, B, C and D were 5.5 $\pm 1.2 ; 5.1$ $\pm 1.0 ; 5.9 \pm 1.8 ; 4.5 \pm 1.5$ million $/ \mu \mathrm{l}$, respectively. The differences were not significant. The mean TLC in groups A, B, C and D were 9.3 $\pm 5.6,10.0 \pm 5.7,5.0 \pm 3.5$ and $6.5 \pm 1.5$, respectively. The TLC in groups A and B were significantly higher than the control.

Total serum protein $(\mathrm{mg} / \mathrm{dl})$ : The mean total serum protein in Group A, B, C and D was $3.4 \pm 0.8,3.7 \pm 1.1,3.7 \pm 1.6$, and $5.2 \pm 0.8) \mathrm{mg} / \mathrm{dl}$, respectively. In problem groups it was significantly $(\mathrm{p}<0.001)$ lower than Group D (Table 2$)$.

Table 1 Haematological values

\begin{tabular}{l|c|c|c|c}
\hline \multicolumn{1}{c}{ Parameters } & Group A $(\mathrm{n}=7)$ & Group B $(\mathrm{n}=10)$ & Group C $(\mathrm{n}=13)$ & Group D $(\mathrm{n}=13)$ \\
\cline { 2 - 5 } & Mean $\pm \mathrm{SD}$ & Mean $\pm \mathrm{SD}$ & Mean $\pm \mathrm{SD}$ & Mean $\pm \mathrm{SD}$ \\
\hline ESR mm/24hr & $9.3 \pm 2.6^{*}$ & $11.1 \pm 5.6^{* * *}$ & $15.5 \pm 7.3^{* * *}$ & $7.5 \pm 1.2$ \\
$\mathrm{Hb}$ gm\% & $10.2 \pm 1.5^{*}$ & $9.6 \pm 1.1^{* *}$ & $9.7 \pm 0.6^{* *}$ & $13.1 \pm 2.6$ \\
$\mathrm{PCV} \%$ & $31.3 \pm 5.2^{* * *}$ & $28.7 \pm 7.0^{* * *}$ & $38.1 \pm 12.8$ & $43.2 \pm 7.9$ \\
TEC million $/ \mu \mathrm{l}$ & $5.5 \pm 1.2$ & $5.10 \pm 1.0$ & $5.9 \pm 1.8$ & $4.5 \pm 1.5$ \\
TLC thousand $/ \mu \mathrm{l}$ & $9.3 \pm 5.6^{* *}$ & $10.0 \pm 5.7^{* *}$ & $5.0 \pm 3.5$ & $6.5 \pm 1.5$ \\
\hline
\end{tabular}

${ }^{*} \mathrm{p}<0.05{ }^{* *} \mathrm{p}<0.01{ }^{* * *} \mathrm{p}<0.001$

Serum bilirubin: The mean concentration of serum bilirubin in group A, B, C and D were $0.6 \pm 0.2,0.3 \pm 0.2,0.4 \pm 0.4$ and $0.3 \pm 0.3$, respectively (Table 2 ). The mean serum bilirubin in Groups A and C was significantly $(\mathrm{p}<0.005)$ higher than Group D $(0.3 \pm 0.3)$. 
Table 2. Serum protein bilirubin and Bovine serum

\begin{tabular}{l|c|c|c|c}
\hline \multicolumn{1}{c|}{ Parameter } & Group A $(\mathrm{n}=7)$ & Group B $(\mathrm{n}=10)$ & Group C $(\mathrm{n}=13)$ & Group D $(\mathrm{n}=13)$ \\
\cline { 2 - 5 } & Mean $\pm \mathrm{SD}$ & Mean $\pm \mathrm{SD}$ & Mean $\pm \mathrm{SD}$ & Mean $\pm \mathrm{SD}$ \\
\hline $\begin{array}{l}\text { Serum protein } \\
(\mathrm{mg} / \mathrm{dl}),\end{array}$ & $3.4 \pm 0.8^{* * *}$ & $3.7 \pm 1.1^{* * *}$ & $3.7 \pm 1.6^{* * *}$ & $5.2 \pm 0.8$ \\
$\begin{array}{l}\text { Serum bilirubin } \\
(\mathrm{mg} / \mathrm{dl})\end{array}$ & $0.5 \pm 0.2^{*}$ & $0.3 \pm 0.2$ & $0.4 \pm 0.4^{*}$ & $0.3 \pm 0.3$ \\
$\mathrm{IgG} \mathrm{IgG}(\mathrm{\mu g} / \mathrm{dl})$ & $807.7 \pm 170.0^{*}$ & $869.6 \pm 109.4^{*}$ & $857.9 \pm 120.0^{*}$ & $1222.2 \pm 178.9$ \\
\hline${ }^{*} \mathrm{p}<0.05^{* *} \mathrm{p}<0.01^{* * *} \mathrm{p}<0.001$ & & &
\end{tabular}

Serum IgG The mean concentration of IgG in groups A, B, C, D was $807.7 \pm 170.0$; $869.6 \pm 109.4,857.9 \pm 120.0$ and $1222.2 \pm 178.9$, respectively (Table 2). The concentration in all problem groups were significantly $(\mathrm{p}<0.001)$ lower than Group D. The result of 3 different bleedings (Table 3 ) shows that the $3^{\text {rd }}$ bleeding before $3^{\text {rd }}$ booster had highest concentration of antibody.

Table 3. Titration of anti-bovine IgG by ELISA (OD at $405 \mathrm{\eta m}$ and serum dilution as five fold)

\begin{tabular}{lcccc}
\hline Serum dilution & $\begin{array}{c}\mathrm{A} \\
(\text { Mean } \pm \mathrm{SD})\end{array}$ & $\begin{array}{c}\mathrm{B} \\
(\text { Mean } \pm \mathrm{SD})\end{array}$ & $\begin{array}{c}\mathrm{C} \\
(\text { Mean } \pm \mathrm{SD})\end{array}$ & $\begin{array}{c}\mathrm{D} \\
(\text { Mean } \pm \mathrm{SD})\end{array}$ \\
\hline Blank & $0.16 \pm 0.00$ & $0.19 \pm 0.00$ & $0.21 \pm 0.00$ & $0.25 \pm 0.00$ \\
0.00000128 & $0.24 \pm 0.00$ & $0.43 \pm 0.03$ & $0.48 \pm 0.01$ & $0.55 \pm 0.01$ \\
0.0000064 & $0.38 \pm 0.00$ & $0.50 \pm 0.03$ & $0.65 \pm 0.03$ & $0.89 \pm 0.03$ \\
0.000032 & $0.45 \pm 0.01$ & $0.73 \pm 0.02$ & $0.89 \pm 0.01$ & $1.23 \pm 0.03$ \\
0.00016 & $0.57 \pm 0.02$ & $1.39 \pm 0.01$ & $1.51 \pm 0.06$ & $2.10 \pm 0.01$ \\
0.008 & $0.78 \pm 0.01$ & $2.10 \pm 0.02$ & $2.74 \pm 0.01$ & $3.02 \pm 0.02$ \\
0.004 & $0.92 \pm 0.00$ & $2.83 \pm 0.04$ & $3.09 \pm 0.05$ & $3.60 \pm 0.03$ \\
0.02 & $1.06 \pm 0.01$ & $3.313 \pm 0.01$ & $3.28 \pm 0.03$ & $4.10 \pm 0.01$ \\
\hline
\end{tabular}

$\mathrm{A}=$ Control; $\mathrm{B}=$ First boostered bleeding; $\mathrm{C}=$ Second boostered bleeding; $\mathrm{D}=$ Third boostered bleeding

ESR is generally high in chronic infection and malnutrition (Samad et al., 1978; Dutta et al., 1991; Islam et al., 1999). Low Hb indicates anaemia and its values are significantly low in all problem groups compared to control. Baqi and Rahman (1981) showed low $\mathrm{Hb}$ in anoestrus cows. The animals in the present study were outpatients at the Veterinary clinic, and had been suffering from gastrointestinal parasites causing anaemia and hyproteinaemia (Murthy et al., 1975). The PCV \% was significantly decreased only in the anoestrus (A) and repeat breeder group (B), but not in the uterine infection group (C) compared to control. PCV is another index of anaemia (Samad et al., 1978; Baqi and Rahman 1981 and Islam et al., 1999). It is difficult to 
interpret the TEC as these were not significantly different from the control. TLC in anoestrus (A) and repeat breeding (B) cows was significant higher than in control group, but the uterine infected animals were not significantly different from the control. Possibly bacterial infection was present in these two groups. Indeed, chronic microbial infection may cause endometritis that may be responsible for repeat breeding and anoestrus (Jahan and Myenuddin, 1996). Total serum protein was low in all subfertile groups compared to control which may indicate malnutrition. SafaaYessein et al. (1995) found no difference in total protein between cows with active ovaries and those with inactivate ovaries group.

In the present investigation, total serum bilirubin was higher in anoestrus and uterine infected animals than in control: this may have been due to liver fluke infestation.

The serum IgG in all subfertile groups was significantly $(\mathrm{p}<0.001)$ lower than control. This could indicate that lower humoral immunity is a factor in subfertility in zebu cows. Indeed, humoral immunity is low in cows with reproductive disease (Dhaliwal et al., 1996; Sanin et al., 1999). The results showed that the $3^{\text {rd }}$ bleeding before $3^{\text {rd }}$ booster dose had highest concentration of antibody against bovine IgG. In one hand, the mean value of anti-bovine IgG were highly significant $(\mathrm{P}<0.01)$. The total anti-bovine IgG was higher probably due to immuno-potentiating action against bovine IgG treated rabbit (Bari et al., 1997).

It is concluded that there is no specific haematological, biochemical or immunological marker for specific reproductive problems in cows. Non-specifically ESR values were high in all reproductive disorders in the cows; however the $\mathrm{Hb}$ and PCV values were low. Humoral immune responses are non-specifically lower in all subfertile cows than the control group.

\section{References}

Albin A, Gustafsson H, Rodriguez Martinez H, Larssor K 1989: Development of day 7 bovine demi-embryos transferred into virgin and repeat heifers. Animal Reproduction Sciences 21161.

Bailey NTJ 1981: The use of t-test for small samples. Statistical methods in biology. $2^{\text {nd }}$ edn. Hodder and Stoughton, Great Britain, pp. 43-51.

Baqi MA, Rahman MM 1981: Study on some Hematological values of dioestrus and Anestrus cows of Palona Breed. Bangladesh Veterinary Journal 2115-18.

Bari ASM 1997: Enzyme linked Immunosorbent Assay for Antinuclear Antibodies in Canine arthropathy. Bangladesh Journal of Animal Science 26 1-2.

Bari ASM 1989: Autoimmunity of canine joint diseases. PhD Thesis. University of Liverpool, UK, pp. 70-76.

Chowdhury MK, Shmasuddin M, Bhuiyan MMU, Alam MGS 1998: Bovine luteal response to prostaglandin preparation available in the local market. The Bangladesh Veterinarian 15 7-12. 
Coffin DL 1953: Manual of Veterinary Clinical Pathology. $3^{\text {rd }}$ edn. Comstock Publishing Associates, London pp.158-186.

Dhaliwal GS, Murray RD, Dobson H, Montgomery J, Ellis WA, Baker JR 1996: Presence of antigen and antibodies in serum and genital discharges of heifers after experimental intrauterine inoculation with Leptospira interrogans serover hardjo. Research in Veterinary Science 60 157-162.

Dutta JC, Basman NN, Barua RB 1991: Blood biochemical profile and microbial spectrum in repeat breeder cows. Indian Veterinary Journal 68 435-438.

Harrison SP, Barlow IM 1989: Three direct spectrophotometric methods for determination of total bilirubin in neonatal and adult serum, adapted to the Technicon RA-1000 analyzer. Clinical Chemistry 35 1980-1986.

Hoeben D, Monfardini E, Opsomer G, Burvenich C, Dosogne H, Kruif Ade, Beckers JF, dekruif A 2000: Chemiluminescence of bovine polymorphonuclear leucocytes during the periparturient period and relation with metabolic markers and bovine pregnancyassociated glycoprotein. Journal of Dairy Research 67 249-259.

Islam MS, Myenuddin M, Talukder MJR 1994: Biochemical studies on repeat breeding cross-bred cows. Bangladesh Veterinary Journal 28 45-48.

Jahan S, Myenuddin M 1996: Haemato-biochemical changes in repeat breeder cross-bred cows with previous history of retained placenta. Bangladesh Veterinary Journal $\mathbf{3 0}$ 73-75.

Jainuddin MR, Hafez ESE 1993: Reproductive Failure in Female. In: Reproduction in Farm Animals. $6^{\text {th }}$ edn. Lea \& Febiger Philadelphia, USA, pp. 261-286.

Johnstone A, Thorpe R 1987: Immunochemistry in Practice. 2nd edn. Blackwell Scientific Publication, London, pp. 254.

Kang BK, Choi HS, Son CH, Oh KS, Kim SJ 1995: Progesterone assays as an aid for improving reproductive efficiency in dairy cattle. V. Plasma progesterone determination as applied to the differential diagnosis of reproductive disorders and judgment of treatment responses to $\mathrm{PGF}_{2}$ alpha or $\mathrm{GnRH}$ treatment. Korean Journal of Veterinary Research 35 603-613.

Lowry OH, Rosebrough NJ, Farr AL, Randall RJ 1951: Protein measurement with the folin reagent. Journal of Biological Chemistry 193 265-275.

Murthy GVK, Nanjiah RD, Muthy BSK 1975: Bacterial flora of cervical mucus in repeat breeding bovines. Indian Veterinary Journal 51 264-268.

Saffa-Yessein, Shawki H, Bashandy MM, Essawy S, Ibtihal-Abdallah 1995: Clinicopathological studies in female subfertility buffaloes. Buffalo Journal 11 83-89.

Saini OPS, Nanda AS, Grewal AS, Singh J 1999: Uterine defense modulation for the treatment of repeat breeding due to infectious endometritis in bovines. Indian Journal of Animal Science 695.

Samad MA, Rahman A, Ali KM 1978: A note on certain blood chemical and hematological values of repeat breeding heifers caused by granular vulvovaginitis. Indian Journal of Animal Science 48 620-622.

Serur BH, Farrag AA, Gomaa A 1982: Incidence of certain infertility problems among cows and buffaloes in Upper Egypt. Assiut Veterinary Medical Journal 10 209-214. 
Shamsuddin M, Alam MGS, Ahmed JU 1988: Reproductive disorders of crossbred cows. Bangladesh Veterinary Journal 22 121-128.

Sheldon IM, Noakes DE, Rycroft AN, Dobson H 2003: The effect of intrauterine administration of estradiol on postpartum uterine invoilution in cattle. Theriogenology 59 1365-1371.

Vale WG 1997: Reproductive disorders in dairy cows and buffalo females reared in the tropics. Proceedings XII, Congress Brasileiro de Reproducao Animal. Revista Brasileira de Reproducao Animal 2 70-77.

Zemjanis R 1980: Repeat Breeding or conception failure in cattle. In Morrow DA (edn), Current Therapy in Theriogelogy, Philadelphia, PA, WB Saunders Co, USA. 